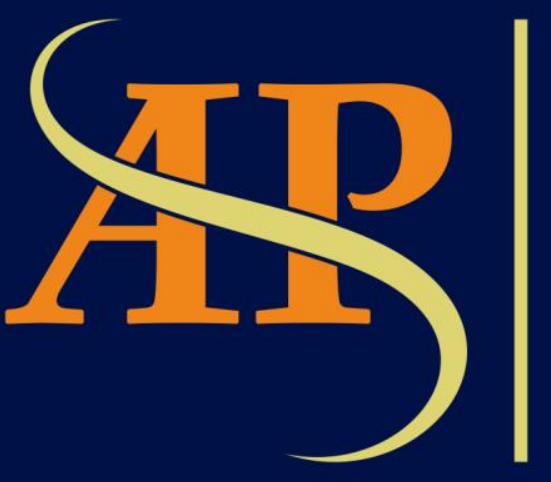

JURNAL

ASIA

PACIFIC

STUDIES

Journal of International Relations Study Program Faculty of Social and Political Sciences Universitas Kristen Indonesia

Volume 3 | Number 2 | July - December 2019 


\title{
DECENTRALIZATION AND CORRUPTION IN POST- 1998 CRISIS ASIA IN IMF ASSISTANCE RECEIVER COUNTRY
}

\author{
${ }^{1}$ Darynaufal Mulyaman, ${ }^{2}$ Achmad Ismail \\ Indonesian Institute of Advanced International Studies (INADIS), \\ Jalan Iskandarsyah Raya No. 1A, Jakarta Selatan, DKI Jakarta, 12160, Indonesia \\ 11dary@inadis.org, ${ }^{2}$ Achmad.ismail71@ui.ac.id
}

\begin{abstract}
Rapid action must be taken by countries to handle the 1998 Asian crisis, one of which is through IMF loans, hopefully by promoting economic development. Unfortunately, IMF recipient countries must adjust the prescription of good governance ala IMF is identical to decentralization, as a result the power from the central government is distributed to the regional government. The presence of this prescription makes corruption still exist even more extends to the regional level. The article argues that the conditions of corruption in several Asian countries that receive IMF assistance still exist, even extending to the regional level where this is closely related to the IMF prescription which is identical to the concept of decentralization. This article focuses on several IMF recipient countries, namely Thailand, South Korea, the Philippines and especially Indonesia. This article uses a qualitative research method with a case study approach. In conclusion, the application of this concept, checks \& balances must be further improved because power is distributed to the regional level so that corruption in the country becomes more resolved.
\end{abstract}

Key Words: Corruption, Decentralization, International Development, Asian Crisis

\begin{abstract}
Abstrak
Tindakan cepat harus dilakukan oleh negara untuk mengatasi krisis Asia 1998, salah satunya dengan pinjaman IMF dengan harapan adanya promosi pembangunan ekonomi. Sayangnya negara penerima pinjaman IMF harus menyesuaikan preskripsi good governance ala IMF identik dengan desentralisasi, akibatnya kekuasaan dari pusat terdistribusikan ke daerah. Hadirnya preskripsi tersebut membuat korupsi masih tetap ada bahkan lebih meluas hingga ke tingkat daerah. Artikel berargumen bahwa kondisi korupsi di beberapa negara Asia penerima bantuan IMF masih tetap ada, bahkan meluas hingga ke tingkat daerah dimana hal ini erat kaitannya dengan preskripsi IMF yang identik dengan konsep desentralisasi. Artikel ini berfokus pada beberapa negara penerima bantuan IMF yaitu Thailand, Korea Selatan, Filipina dan khususnya Indonesia. Artikel ini menggunakan metode penelitian kualitatif dengan pendekatan studi kasus. Pada kesimpulannya, penerapan konsep ini, check \& balance harus lebih ditingkatkan karena kekuasaan terdistribusi ke tingkat daerah sehingga korupsi yang terjadi di negara tersebut menjadi lebih teratasi.
\end{abstract}

Kata Kunci: Korupsi, Desentralisasi, Pembangunan Internasional, Krisis Asia

\section{Introduction}

Good Governance is a system of governance management that is based on transparency and good accountability. A government, from the local, national, supranational, and international levels, should have good governance. Governance that does not overlap, 
transparently, has good accountability, and is precisely targeted and efficient is usually the general idea of how good governance should be.

Good governance according to Yap Kioe Sheng (2009) "Good Governance has 8 major characteristics. It is participatory, consensus oriented, accountable, transparent, responsive, effective and efficient, equitable and inclusive and follows the rule of law. It assures that corruption is minimized, the views of minorities are taken into account and that the voices of the most vulnerable in society are heard in decision-making. It is also responsive to the present and future needs of society. ". This means that, good governance must minimize corruption and meet elements of participation, consensus, transparency, accountability, responsive, effective, efficient, equal, and inclusive complying with prevailing and impartial legal rules. And fair share of the country's recognized customs, race, religion, and gender.

Then, according to Rachel Gisselquist (2012) "Good governance' ' is an extremely elusive objective. It means different things to different organizations, not to mention to different actors within these organizations (to make matters even more confusing, governance experts also routinely focus on other types of governance - global governance, corporate Governance, IT governance, participatory governance, and so on ". Then Kofi Annan (in un.org, 1998) said that "Good governance is perhaps the single most important factor in eradicating poverty and promoting development". Aside from that, Jomo Kwame Sundaram (2015) said that "To be sure, governance that is effective, legitimate, and responsive provides untold benefits, especially when compared to the alternative: inefficient governance, cronyism, and corruption. Yet the focus on governance reform has not proved nearly as effective as promised in fostering development. Recognizing that governance improves with development, the international community would be better served by pursuing reforms that directly advance development, instead of a broad agenda that may have, at best, a small indirect impact."

In the statements above, it can be concluded that the concept of Good Governance is the best way to promote development, especially after the economic crisis. Thus the domino effect is expected to reduce poverty, corruption and so on. So that development efforts undertaken on a national and international scale are comprehensive. The concept of this idea is reflecting of the experience of the Latin American crisis in the 1980s. One of the goals is to establish economic management that underlies structural adjustment and stabilization programs by Bretton Woods institution for the creation of a "perfect market" to enhance economic growth.

John Williamson (1990) was the person who formulated the Washington Consensus with the aim of economic stability through controlling demand for money, providing a set of assistance for private sector activities, in a decentralized way. He also lowered the Washington Consensus into 10 prescriptions, among them, (1) Fiscal discipline, (2) Redirecting public expenditure, (3) Tax reform, (4) Financial liberalization, (5) Adoption of a single, competitive exchange rate, (6) Trade liberalization, (7) Investment liberalization, (8) Privatization, (9) Deregulation, (10) Secure property rights. These ten prescriptions become the mainstay tools for the two world financial institutions (IMF \& World Bank) to help developing countries affected by the crisis, poverty reduction and so on.

Naim (2000) sees the role of Washington Consensus "reform the government wherever it shows how policy objectives are only a few years old, or even a few months, have previously been designated as the deadline for the reform process Be just a prerequisite for success. New destinations, more complex, and more difficult continue to be added to the list of requirements for acceptable performance". The government's recommended IMF is a government reform following the ten-grain contents of Washington Consensus as a prescription to heal the prevailing governance weaknesses. 
The effectiveness of the concept of good governance was tested to answer the 19971998 Asian crisis. The crisis that struck Asia in 1998 was widely described as a result of too much intervention from the country to the country's economic system. The crisis that occurred in the year 1998 spread from one country to another. The crisis not only struck the economic dimension but also other social dimensions. The 1998 Asian crisis occurred in various countries, there are Thailand, Korea, Indonesia, Malaysia and the Philippines. The biggest impact of the crisis cause on Thailand because of the decline of Bath. For Korea itself due to weak financial system because of government interference to the economy and relation of the Bank and conglomerate. The decrease in the value of Bath also affects Indonesian Rupiah plus the weakness of Indonesia's financial sector structure and the contribution of the magnitude of private sector debt that contributes to reduced trust, the government's ability to control eye value Money. While the Philippine is a major factor is the disrespect of foreign investors to the government as experienced by Indonesia like according to IMF (IMF, 2000).

The concept of good governance ala IMF which aimed to promote development, economy do not implemented as expected. In reality, it makes country more difficult to return the debt and its debt interest. Not to mention there are political and economic consequences caused by adjusting regulations in accordance with the values of liberalism (Bretton Woods System). Especially the concept that adhere to the decentralization value, increasing corruption in various regions. Regions are given full authority to regulate finances, development and so on. This has become a new problem hole as a consequence of receiving assistance from the IMF with applying the concept of good governance ala IMF.

This is experienced by Thailand, the Philippines, South Korea and Indonesia. In these countries, after receiving IMF assistance with applying the requirement the concept of good governance ala IMF with decentralization, corruption increases at the regional level, especially in elections. This is in line with Hutchroft's statement in Hadiz (2006) said the decentralization that became one of the IMF's prescription was run by Indonesia and the Philippines, but the political clan still dominated the government, so that money politics still polluted and Intimidate the selection process. This means that Indonesia is running a decentralized program as a SAP IMF requirement to issue aid funds during the 1998 financial crisis. Therefore, research question in this article "how is the condition of the recipient countries of IMF assistance after the 1998 economic crisis especially in corruption?".

This article argues that countries in Asia, especially Indonesia, after accepted IMF assistance with applying the requirement the concept of good governance ala IMF with decentralization, making corruption in these countries are still happen. Of course this has a close relationship, fast action must be taken to overcome the economic crisis, one of them with IMF financial assistance. But there are requirements that must be applied with the conditions of implementing good governance ala IMF which is identical to decentralization, as a result the power held fully by the central government is distributed to the regional government. In this phase the practice of corruption increased dramatically, initially the opportunity for corruption only at the central level decreased to the regional level.

\section{Theoretical Framework}

This study will conduct analysis through what Vedi Hadiz (2006) have mention that corruptor in Indonesia as an elite predator has grown since the Soeharto regime. Predator has learned how to get around democracy, one of which is learning how to win a direct electoral system and adjusting to good governance to continue to dredge public resources for personal or group interests. They intend to divert public resources for the benefit of their own company 
or family or budget allocation and government facilities for the benefit of a particular business group.

In addition, Hadiz also argues that in a new democracy environment, the practice of corruption is likely to be harder to eradicate because it is rooted in the center of power. Hence, Hadiz criticized the Neo-Institutionalist theory that the neoliberal reform efforts proclaimed by a number of international institutions in a number of poor and developing countries are believed to result in work patterns and effective new governance order to prevent corruption. But in practice, according to Hadiz, the democratic institutions and anti-corruption institutions have precisely been ruled by the interests of the predator politicians.

The predator politicians sought to create barriers of bureaucratic and political chaos to prevent them from anti-corruption investigations. These efforts are done on behalf of the "Democratic agenda" and the creation of good governance. In fact, they keep trying to make the actual system and regulation still a lot of shortcomings and weaknesses. The predator elites have trapped democracy into unwholesome, corrupt, and gross politics. Therefore, the phase of political transition to democracy becomes very prolonged, and it ends up not clearly the terminus, and forces the country to be in a future path that cannot be determined.

In the context of the post-New order, predator corruption interests remained dominated by the military, political parties, parliaments and civil bureaucracy at the national level, and provinces. Such interests have a great urge for anti-corruption prevention. The real advances in combating corruption ultimately depend on the success of clearing the politically dominant coalition. Yet it requires social and political power which is an unpleasant idea for most Neo-Liberals.

The struggle to eradicate corruption thus implicitly involves the power of civil society. Because it simply relies solely on the country, the epicenter of corruption is unlikely. When the legislature, executives and judiciary are already equally corrupt, then civil society becomes an important element that can control. Therefore, as Hadiz said, the oligarchs in Indonesia were essentially not fallen after the Reformation or fall of Suharto. The oligarchs raised by the Suharto regime continued to transform by adjusting the political context in Indonesia driven by neoliberalism schemes. It was emphasized by Jeffrey Winters by mentioning that Indonesia's post-New order did not undergo a fundamental change, but only the change from "The Sultanic Oligarchy" to "The Wild Oligarchy". The regional leaders transform into "Little kings" within its region or area.

Closely related to the world Neo-Liberal reform agenda in Washington Consensus with increased corruption in Indonesia. In this context, some debate arises. For Neo-Liberal activists consider that a crisis of even increased corruption in Indonesia is the fruit of some weaknesses in the regulation in the state higher institutions systemic and back to the weakness of the integrity of the individual against corruption. While for Counter-Neo-Liberalists activists said that by the existence of Neo-Liberal values made changes in the governance so that implicates the creation of corruption, not only at the national level, but also on the provincial and local level.

Hence at this configuration it remains that there are several actors in the new Order sustain themselves into the form of political parties and parliaments. As Robison and Hadiz (2006) suggest, many parts of the old New Order elite, both at the national and local levels, have now reformulated themselves through new alliances, usually expressed politically in the form of Political parties and parliaments. Essentially, the downfall of President Suharto became the earliest marker of reforms that made changes to the electoral system, the emergence of parties in Parliament and the configuration of regional resource management (decentralization). In line with Nico Schulte-Nordholt (n.d.) said that in fact that in an administrative decentralization proposal has facilitated or provided a space for corrupt 
practices in some sectors, particularly in areas rich in sources of such as Kalimantan and Papua. It is becoming one of the real forms of administrative decentralization - the main part of the consensus-based reform pact / SAP Washington Consensus - has initiated a new dynamic of decentralized and locally-driven corruption practices.

President Suharto's regime of three decades, the governance system is centralized, the clear flow of corruption is also centralized by the ruling family of the regime and associates in the governing circle. The next policy, as a package of Neo-Liberal reform should bring Indonesia to good governance, but decentralization does not demonstrate as a proper prescription against the handling of corruption. Corruption is interpreted as the use of public office for personal gain by violating the general rules (Hamilton-Hart, 2001). Political corruption is interpreted as the misuse of power entrusted by political leaders for personal gain, with the intention of increasing strength or wealth (Harris, 2003). The main objective of Neo-Liberal reform is that corruption impacts investment and economic growth. Dick (2002) said that The World Bank often ignored the corruption of Suharto's era with subtle way.

\section{Research Methods}

This article uses qualitative research methods with a case study approach. According to Neumann (2014) adding that case study research intensively investigates one or a small group of cases, focusing on many details in each case and its context. Data collection techniques in this article use data from various sources, such as books, scientific journals, documents and articles from related online media.

\section{Result and Discussion}

\subsection{Corruption in Post- 1998 Crisis Asia}

The practice of corruption has been running for a long time in many countries to date. But if this corruption had only occurred at the central/national level, after the 1998 crisis that forced some countries affected by the crisis received IMF assistance with "prescription" of SAP, made a fundamental administrative change is one of the points is eradication of trade barriers in a decentralized way. It is essentially an international responsibility to provide international development assistance that makes it important for national development. It is at this point that more and more individuals are empowered at the provincial level and so are given the authority to regulate the region's resources and finances. It is good to weigh that efficiency in economic activity at lower levels is increasingly needed, but on the other hand it has an impact on misuse of authority by practicing corruption at the area of their respective areas.

For example Kongleaphy Keam (2017) said that "the Thai anti-corruption organization mentions that the governor of Phuket, Chokchai Dejamorthan, allegedly practiced corruption in the form of bribery to facilitate illegal investment in Phuket as there 85 percent of illegal hotels, tour companies, bars and club owners, restaurants, shopping centers, dive schools, language schools and vehicle rental businesses. " Not to stop here, the practice of corruption by the governor of Phuket occurred in several sectors, such as bribery to register as migrant worker, corruption of the construction project of Khong Katha Dam. Seeing this phenomenon, signifying that the existence of power held at the regional level due to decentralization makes the practice of corruption flourishing. There was even a political coup by the Thai military junta previously held by Yingluck Shinawatra and now General Prayut Chan-Ocha due to 
allegations of corruption practices carried out by the family of Shinawatra and some of his political associates to undo the Shinawatra political clan.

But uniquely, according to Neil Thompson (2018) while after the 2014 military coup, the National Council for Peace and Order (NCPO) on several after the 2014 coup, the corruption in Thailand was widely held to deteriorate under the NCPO, partly because the court Thailand lost their constitutional independence after the coup and was politicized, of which the security service itself is widely regarded as the most corrupt part of the country of Thailand. This increased corruption practice continues to occur, even the Transparency International's Corruption Perception Index puts Thailand's corrupt country on the number 37 from 100 countries - the bigger the numbers, the cleaner.

Other countries such as the Philippines also face the same problem. Carlos Conde (2007) added that in 2007, expatriate entrepreneurs in Asia regarded the Philippines as the most corrupt country in the region, a systemic corruption even according to the UNDP of nearly $\$ 2$ billion dollars, or about 13 percent of its budget Annual Philippines, lost due to corruption in the country every year. The authors cite from the page (news.abs-cbn.com, 2017) The Philippines was assessed to have a high level of government corruption in 2016, continuing its trend from the previous year with a score of 35 from 100 in Transparency International's Corruption Perception Index, similar to the previous year's score. This suggests that the practice of corruption in the Philippines still remains matter even more widely visible.

Another example of this point occurs in the country of South Korea. In the country of South Korea, this corruption practice is more alarming considering that corruption actors are former presidents in the country. Not long ago, two former presidents, Lee Myung Bak and Park Geun-hye, were sentenced to misuse of corruption authorities and practices. Then, former president Park was sentenced to 24 years imprisonment over 16 out of 18 charges for coercion of companies signing agreements that benefited his best friend Choi Soon-Sil and divulged the state's secret documents to Choi for its importance that made South Korea lose US \$17 million (BBC, 2018). On the other hand, former president Lee Myung Bak was convicted of corruption by receiving bribes of more than 10 million dollars from several companies to its interests also embezzled 30 million dollar funds of the DAS vehicle parts company (voaindonesia, 2018). It is exacerbated that after the independence of South Korea there were at least 5 former presidents who were ensnared by corrupt practices, Chun DooHwan, Roh Tae-Woo, Roh Moo-Hyun, Lee Myung Bak, Park Geun-Hye.

Then, in Indonesian case, the signing of the IMF funding assistance by the Indonesian Government certainly has a continuous impact in the domestic government order. There is regional autonomy that gives more rights to the region in regulating various sectors, such as finance, local regulations, development projects and so on. This phenomenon becomes positively noticed that the area is more active in taking care of all their needs. But this is also a negative starting point, seeing that the level of corruption in Indonesia is experiencing significant improvement. The chart above shows that the post-Indonesia received the IMF loan aid with 9 Structural Adjustment Program (SAP) has its own implications for the increasing number of corruption in Indonesia.

Further, one of the points of the SAP has deregulation points, in which it requires that Indonesia provide elimination of regulations that impede competition to provide some fundamental changes to the regulatory and governmental settings in Indonesian. This fundamental change gives the creation of corruption in Indonesia. In 2000, for example, a survey by Hong Kong-based Political Economy Risk Consultant (PERC) showed that expatriates working in Asia viewed Indonesia as the corrupt country in the Asian continent like Hadiz said (2006). Many local government institutions both legislative and executive are 
the main players of the corruption Act. Indonesia has a bad record in terms of corruption in the world.

Ninis Chairunnisa (2018) said that "Indonesia Corruption Watch released, in the year 2017, Indonesia's loss due to corruption of $6.5 \mathrm{~T}$ and bribery of $211 \mathrm{M}$ rupiah, the figure rose from the year 2016 even the increase occurred in the magnitude of suspect Corruption". Ervan Hardoko (2018) then added that "The research from Transparency International released data that Indonesia is a country ranked 96 with the perception index of corruption in the world and in southeast Asia alone, Indonesia is still being brought to Singapore (6), Brunei Darussalam (32), Malaysia (62) and East Timor (91)". Therefore, based on the data above, the data indirectly describing that there is assistance from the IMF with its neoliberal values, particularly in point 9 the SAP of the Washington Consensus system affects the adjustment of government order by forming regional autonomy. Thus, it is at this stage an opportunity for increased corruption in Indonesia because the region is given delegation to regulate its region. Of course with Indonesia being in the ranks 96 make Indonesia has low collective position in international context. Moreover it will be a problem for investors to invest in Indonesia.

\subsection{Indonesia Case}

Regional autonomy or the division of power between the central government and local governments in the new Order period, was originally present as a new policy to correct the failure of the old order government. The policy as taken by the President of Indonesia at the time, General Suharto, who is also a revolutionary figure of independence presented in the opening of the extraordinary Congress of the Unity and integrity of the Indonesian National Party as Was said by Herbert Feith and Lance Castles (1988) states the following, the decentralization policy is taken to address,

1. PKI radicalism

2. The occurrence of political opportunism driven by the personal ambitions of the ruler

3. The occurrence of economic malpractice.

Then, with the presence of law No. 5 of 1974 about the local government is intended to be able to make regional stability, so by executives to authorize a large local government to become a leader and manager in areas for prosperity (Kemenkeu, 1974). Nevertheless, the law stated that the local government was composed of the provincial leader and the provincial parliament, then for the city or regency area, there are the leaders of city or regency and its parliament I. Despite the democratic impression, in reality is not democratic. Ongoing elections have no good accountability. Because as in the center, the local parliament in the region is only a reseller and a successor to what has been established by the central government.

Hence, it can be concluded, the regional head selection that the local parliament can possibly be referred to as rhetoric, because who should be the regional leader has been set before, so it is set. With this scenario, there are candidates who are featured by the central government, and if it is not elected, then the central government will choose or lift again the person who has been re-elected, because the results of the local parliament and local election was then submitted to the central government and the central government can determine who will be appointed from the results of the proposed election. 
Indonesia's Reformation in 1998 was marked by the decline of Indonesia's second president, President Suharto and replaced by B. J. Habibie who previously served as vice president. The Reformation Era was seen as the beginning of decentralized creation. Although the issue of decentralization has long evolved, the implementation of which is considered real happens during the Reformation. Law No. 22 of 1999 on local government and law No. 25 of 1999 on financial balance between the central and local governments is a real step by the government of Indonesia.

Act No. 22 describes the basic framework for the decentralization of power consisting of 134 articles. Meanwhile, Law No. 25 explains more about the financial aspects of such decentralization and has 33 chapters in it. The law is intended to improve the welfare of people in the region, improve the quality of public services in the region, and increase the competitiveness of each region. The role of the central government becomes limited only to matters relating to defense, foreign policy, macroeconomics, judiciary and religion. Along the way reform, the decentralization of power becomes decentralized corruption.

In order to achieve decentralization, Rinaldi, et.al. (2007) explained that decentralization carries implications for the shifting of central power relations - regions and between institutions in the region. Various changes opened the opportunity of "money politics" by the regional head to acquire and maintain support from the legislature, the utilization of various sources of financing by legislative members as a deposit for political parties as well - which most common, is the desire to enrich oneself. Corruption opportunities are increasingly open with the difference/inconsistency of regulations issued by central and local governments, "cooperation" between legislative and executive and lack of portions of participation and public supervision.

\subsection{Decentralization and Corruption in Indonesia}

The IMF's prescription decentralization is strengthened by the law No. 22 of 1999 which provides a decentralized framework of authority and responsibility from Jakarta to the province. In any case, the rules also accommodate the regional demand for successful autonomy in resource management and in the implementation of economic and political authorities. This Neo-Liberal concept is expected to address corruption issues in Indonesia, decentralization will help to create a greater responsibility from the new form of government that is transparency, participatory and also market-friendly.

Hence the fact of decentralization in Indonesia has shown patterns to be an agenda that gives corruption easier by directly. Hadiz (2006) said that instead of creating favorable conditions for investment, a new form of corruption in decentralization helped create business uncertainty. In addition to the provincial decentralization of the capital, decentralization has also been happened in the districts of the province, which gets its own autonomic authority. With decentralization, the regional political observer saw that only the wealthier who could win the political position, gave the party and parliament the opportunity to be less encouraged to accept candidates who were able to undertake the political money.

Conditions that provide money politics in political position nomination provide a space to entertain the corruption in provincial and regional areas. Corruption in Indonesia, experienced a drastic increase over the year. Other example of corruption in Indonesia in this paper are corruption cases in three regions in Indonesia with various characteristics of corruption cases, such as Banten, Riau, and North Maluku. If noted from the examples of the following cases, it seems to justify the corruption occurring in Indonesia in multi-sectors and almost all parts of Indonesia, from the west to the east. 
In Banten case, is one case of corruption that makes Indonesian people was shock. The reason is that corruption is done in a very broad, meaning that it is done by the executive, judicial and legislative institutions, also from provincial to national level. This corruption case began in the range from 2012 to 2014, where the governor of Banten at the time, Ratu Atut Chosiyah allegedly committed corruption in 3 cases at once. First, election disputes of Regent Lebak, Banten in the Constitutional Court. Second, the corruption of procurement of medical equipment and infrastructure in Banten region 2011-2013. Thirdly, gratification of 2011-2013 health equipment project in Banten as quoted from the (Tempo, 2017). This act of corruption can be said to be an act of corruption in the event that there are 1 important actors who play in the act of corruption in 3 cases of corruption. At least the losses suffered by the state of this corruption act amounted to Rp 79 billion (Detik, 2017).

Atut performs self-enriching actions, families and others. This corruption case became a massif when in the case of election dispute of the Regent Lebak Banten, Ratu Atut with Tubagus Chaeri Wardhana/Wawan (brother of Atut) bribing the chairman of the Constitutional Court, Akil Mochtar with the intention to dispute the election of Lebak, Banten won by Tubagus Chaeri Wardana. Atut and Wawan bribe Akil Mochtar with money worth 1 billion rupiah through its lawyers, which can also be part of Rp 700 million. While in 2 other cases related to the procurement of medical equipment in the Banten government environment, Ratu Atut made corruption amounting to Rp 3.8 billion and Wawan amounting to Rp 50 billion as well as some officials of the health office of Banten Province, some members of local parliament of Banten.

If explored further, the presence of Neo-Liberalism values with the inclusion of SAP from Washington Consensus made the configuration of the Indonesian government administration to change towards decentralization that makes spaces to grow the practice increasingly fertile corruption. Even some scholar agreed that the existence of this decentralized configuration is an important factor in the practice of corruption grows, so it is no longer awaiting approval or control of the central government.

As an example of another case in the analysis of this article, this article tried to see a case of corruption conducted by the governor of Riau Province in 2010. In 2010, the Corruption Eradication Commission (KPK) announced Riau governor Rusli Zainal as a suspect in three cases of alleged corruption. First, the case of prize acceptance related to the revision of local regulation No. 6 of 2010 related to the addition of construction costs of sports shooting arena in Riau 2012 National Games. Second, gratification related to the discussion of revision local regulation No. 6 of 2010. Thirdly, acts against the law or misuse of authority related to the ratification of the work chart of timber use in plantation forest (IUPHHK-HT) in the period 2001-2006 (Kompas, 2013).

Then, KPK ensnare Rusli with Article 12 point A / B or Article 5 Paragraph 2 or Article 11 of the Corruption Act of Eradication juncto Article 55 Paragraph 1, 1st of the Criminal Code for the first case. Thus, for the second case, Rusli is deemed by KPK to violate Article 5 Clause 1 point A / B, then Article 13 of the Corruption Criminal Eradication Act juncto Article 55 Paragraph 1, point 1 of the Criminal Code. Then, for the third case, Rusli is ensnared with Article 2 Paragraph 1 or Article 3 of the Corruption Eradication Act juncto Article 55 Paragraph 1, 1st of the Criminal Code.

In addition to the alleged corruption about regulation regarding Riau 2012 National Games, Rusli Zainal has also been suspected of committing acts against the law or misuse of authority in the validation of the work chart IUPHHK-HT 2001-2006 in Pelalawan, Riau. In this case, Rusli Zainal is known to authorize an annual work plan or an UPHHKHT RKT to 10 companies in Pelalawan in 2004. In addition to Governor of Riau, Rusli Zainal, this case 
has ensnapped the former regent of Pelalawan, Tengku Azmun Jafar, and former regent of Siak, Arwin U.S, who had even been convicted.

Later, one of the other case studies that could explain decentralized relations and corruption was a corruption case for the governor candidate of North Maluku. The case also explained that there has been "cooperation" between the executive and legislative parties. In fact, according to some political observers, that the corruption committed by the prospective governor of North Maluku is an attempt to defend his power by making money politics.

The Corruption Eradication Commission (KPK) established the prospective governor of North Maluku, Ahmad Hidayat Mus, as a suspected corruption case in the land acquisition of Bobong Airport in the Sula Islands District budget year 2009. In addition, KPK also established the former chairman of the District Parliament of Sula, Zainal Mustafa. Deeds of Ahmad Hidayat Mus allegedly led to the state financial losses amounting to Rp 3.4 billion. From the sum of the total of Rp 3.4 billion of the district of Sula Islands Regency, Rp 1.5 billion was allegedly transferred to Zainal Mustafa. Zainal Mustafa is the acting holder of the land release payment. While Rp 850 million received by Ahmad Hidayat Mus through other parties with the intention of disguise. The operation mode is the Sula Archipelago Regency government appeared as buying a land belonging to Zainal Mustafa so community was seen like purchased the land. For his actions, the two suspects allegedly violated Article 2 Paragraph 1 or Article 3 of the Law No. 31 of 1999 on the eradication of corruption crimes as amended by Law No. 20 of year 2001 juncto Article 55 Paragraph 1 of the 1st Penal Code juncto Article 64 paragraph 1 of the Criminal Code.

\section{Conclusion}

Good Governance is an important factor in international development when faced with improvement of governance both at local, interlocal, supranational and international levels. In fact, good governance is a term that is not raw related to governance that is participatory, reponsive, effective, transparent and accountable. Nevertheless, good governance should not be a raw recipe given to the developing country/advanced by an international institution in suggesting/granting assistance, as each country is unique and has the complexity of the case The development of their respective country, one of which is related to decentralization.

The IMF-backed decentralization in Indonesia is not accompanied by a good control check \& balance with the value of transparency and accountability as well as qualified resources, so that decentralization resulting in changes in electoral patterns Regional heads, regional representatives, retribution and income areas, regional budgets as well as work patterns between the region and the center provide greater and systematic space for the Corruption Act conducted by district officials. The corruption factor in Indonesia, should not always be the problem of oligarchy as said by Hadiz, apparently there are other factors that deserve to be taken into account such as political decentralization created post-New order. This decentralization makes the new partition and space for corruption wider and wider than it may have only been refractive within the scope of the central oligarchs.

As the decentralization given from the center to local area, apparently, the oligarchs that have been in the central region only, also participated shifted into regional oligarchs and added new corruption space. However, corruption should be suppressed as it may impede development in the case of developing countries. Robust control and synchronization between the region and the center must be aligned and in accordance with the corridors and the prevailing rules so that it does not cause overlap that makes room for corruption grow. As in the case of regional head selection, there should be clear line of direction so that the local 
regulations created by each local government with the spirit of regional autonomy, do not clash with the center.

The establishment of regional level corruption institutions also need to be done so that the alignment of accountability and transparency at the central and regional level can be uniform, so that regional oligarchs can also be reduced, in addition to eradication at the central level also. Then the last is, the establishment or implementation of good governance should also be asserted at the district level so that there is a down-to-top mechanism in the formation of a structured and transparent governance system, according to With a spirit of anti-corruption and regional autonomy democracy through the formation of a special body that oversees apparatus reform at the regional level (such as Kemen PAN-RB / Ministry of Administrative and Bureaucratic Reform at the central level government of Indonesia). 


\section{REFERENCES}

\section{Books}

Dick, H. 2002. "Corruption and Good Governance: The New Frontier in Social Engineering". inside Corruption in Asia: Rethinking the Governance Paradigm, edited by T. Lindsey and H. Dick (eds), 71-86. Sydney: The Federation Press

Feith, Herbert, and Lance Castles. 1988. Pemikiran Politik Indonesia 1945-1965. Jakarta: LP3ES

Hadiz V. R. 2006. "Corruption and Neo-liberal Reform: Markets and Predatory Power in Indonesia and Southeast Asia". inside The Neo-Liberal Revolution, Forging the Market State, edited by Robison R (eds), 79-97. London: Palgrave Macmillan

Hamilton-Hart, N. 2001. "Anti-Corruption Strategies in Indonesia”. Bulletin of Indonesian Economic Studies, 37:65-82.

Rinaldi, Taufik, Marini Purnomo dan Dewi Damayanti. 2007. Memerangi Korupsi Yang Terdesentralisasi: Studi Kasus Penanganan Korupsi Pemerintahan Daerah. Bank Dunia: Justice Project.

\section{Websites}

ABS-CBN News. 2017. "PH still among world's most corrupt countries: Transparency Int'l index". Accessed on 24 May 2019. http://news.abs-cbn.com/focus/01/25/17/ph-stillamong-worlds-most-corrupt-countries-transparency-intl-index

BBC. 2018. "Apa yang membuat mantan Presiden Korea Selatan Park Geun-hye dipenjara selama 24 tahun?”. Accessed on 5 June 2019. http://www.bbc.com/indonesia/dunia-43618151

Chairunnisa, Ninis. 2018. "20 Tahun Reformasi: Pekerjaan Rumah Pemberantasan Korupsi”. Accessed on 24 May 2019. https://nasional.tempo.co/read/1091185/20tahun-reformasi-pekerjaan-rumah-pemberantasan-korupsi

Conde, Carlos. 2007. "Philippines most corrupt, survey says". Accessed on 5 June 2019. https://www.nytimes.com/2007/03/13/business/worldbusiness/13ihtpeso.4891792.html

Fadhil, Harris. 2017. "Kasus Alkes, Ratu Atut Didakwa Rugikan Negara Rp 79 Milliar". Accessed on 24 May 2019. https://news.detik.com/berita/d-3441349/kasus-alkesratu-atut-didakwa-rugikan-negara-rp-79-miliar

Gisselquist, Rachel M. 2012. "What Does Good Governance Mean?.” Accessed on 24 May 2019. https://www.wider.unu.edu/publication/what-does-good-governancemean

Hardoko, Ervan. 2018. "Indeks Persepsi Korupsi 2017: Peringkat Indonesia di Bawah Timor Leste". Accessed on 5 June 2019. https://internasional.kompas.com/read/2018/02/26/14444501/indekspersepsi-korupsi-2017-peringkat-indonesia-di-bawah-timor-leste

Harris, R. 2003. Political Corruption in and Beyond the Nation State. London: Routledge

IMF. 2000. "Recovery from the Asian Crisis and the Role of the IMF". Accessed on 4 June 2019. https://www.imf.org/external/np/exr/ib/2000/062300.htm

Keam, Kongleaphy. 2017. "Anti-corruption boss says Phuket 'most corrupt' in Thailand". Accessed on 5 June 2019. https://thethaiger.com/news/phuket/Anticorruption-bosssays-Phuket-corrupt-Thailand 
Kementerian Keuangan. 1974. "Undang-Undang No.5 Tahun 1974”. Accessed on 25 May 2019. http://www.jdih.kemenkeu.go.id/fullText/1974/5TAHUN 1974UU.HTM

KPK. N.d. "Rekapitulasi Tindak Pidana Korupsi". Accessed on 24 May 2019. https://acch.kpk.go.id/id/statistik/tindak-pidana-korupsi

Naim, Moises. 2000. "Fads and Fashion in Economic Reforms: Washington Consensus or Washington Confusion?". Third World Quarterly, 21:505-28. DOI: 10.1080/01436590050057753

Rastika, Icha. 2013. "Ada Tiga Kasus yang Menjerat Gubernur Riau Rusli Zainal”. $\begin{array}{llll}\text { Accessed } & \text { on } & 25 & \text { May }\end{array}$ https://nasional.kompas.com/read/2013/02/08/14514588/Ada.Tiga.Kasus.yang.Me njerat.Gubernur.Riau.Rusli.Zainal

Schulte-Nordholt, N. n.d. "Pelembagaan Civil Society dalam Proses Desentralisasi di Indonesia". $\quad$ Accessed $\quad$ on $24 \quad$ May 2019. http://www.knaw.nl/indonesia/transition/workshop/work_in_progress02.pdf

Sundaram, Jomo Kwame. 2015. "Does good governance always boost development?". Accessed on 6 June 2019. https://www.weforum.org/agenda/2015/06/does-goodgovernance-always-boost-development/

Tempo. 2017. "Atut Dijerat 2 Kasus, Suap Sengketa Pilkada Hingga Alat Kesehatan". Accessed on 24 May 2019. https://nasional.tempo.co/read/858316/atut-dijerat-3kasus-suap-sengketa-pilkada-hingga-alat-kesehatan

Thompson, Neil. 2018. "Corruption in Thailand: Running in Place". Accessed on 5 June 2019. https://thediplomat.com/2018/04/corruption-in-thailand-running-in-place/

United Nations. 1998. "UNITED NATIONS `INDISPENSABLE INSTRUMENT' FOR ACHIEVING COMMON GOALS, SAYS SECRETARY-GENERAL IN REPORT TO GENERAL ASSEMBLY”. Accessed on 6 June 2019. https://www.un.org/press/en/1998/19980921.sg2048.html

VOA Indonesia. 2018. "Mantan Presiden Korsel Diselidiki dalam Kasus Korupsi". Accessed on 5 June 2019. https://www.voaindonesia.com/a/mantan-presidenkorsel-diselidiki-dalam-kasus-korupsi/4298167.html

Williamson, John. 2004. "The Washington Consensus as Policy Prescription for Development". Accessed on 4 June 2019. https://www.piie.com/publications/papers/williamson0204.pdf

Yap Kioe Sheng. 2009. “What is Good Governance?”. Accessed on 6 June 2019. http://www.unescap.org/sites/default/files/good-governance.pdf 